\title{
Fintech in Microfinance: a new direction for Microfinance institutions in Vietnam
}

\author{
Thuy T. DANG ${ }^{1}$, Huong Quynh VU² \\ Received: October 16, 2019. Revised: November 04, 2019. Accepted: July 05, 2020
}

\begin{abstract}
Purpose: Vietnam's financial sector has grown substantially but microfinance institutions (MFIs) still face up many challenges in providing financial services to underserved customer segments, including small businesses, rural populations, and urban migrants. The recent worldwide explosion of fintech, including in Vietnam, promises to fill this gap. The purpose of this paper is to analyze fintech activities in microfinance sector and recommend for fintech adoption of MFIs in Vietnam. Research Design, Data and Methodology: The paper's data is mainly based on international organizations such as Asia Development Bank (ADB), Food and Agriculture Organization of the United Nations (FAO) and Vietnamese organizations such as Vietnam Microfinance Working Group. The authors suggest new directions for microfinance activities in Vietnam. Results: In recent years, the application of fintech in microfinance sector has brought many good results, such as improving the quality of products and services, easy access to many customer groups, and scaling up the operating model. Conclusion: MFIs in Vietnam have developed new products and services by applying fintech. The application of technology and digital solution has supported MFIs in Vietnam to gradually achieve targeted growth through expanding geographical inclusion/scale, enhancing product supply/provision, helping in-depth customer understanding as well as improving operational efficiency
\end{abstract}

Keywords: Fintech, Microfinance, Direction, Microfinance Institution, Vietnam

JEL Classifications: G21, G28, R11

\section{Introduction}

Microfinance is considered an effective tool in eliminating hunger, reducing poverty, generating income as well as improving living standard for poor people in society. Microfinance has enabled the low-income and the vulnerable to access financial products and services. In recent years, microfinance industry has experienced rapid evolution with the vast change in technology.

1 Dr. Vietnam Institute of Indian and Southwest Asian Studies, Vietnam Academy of Social Sciences (VASS). Vietnam. Email: thuy0183@gmail.com

2 Researcher, Research Institute for Banking, Banking Academy. Vietnam. Email: huongquynh90@gmail.com

(c) Copyright: The Author(s)

This is an Open Access article distributed under the terms of the Creative Commons Attribution Non-Commercial License (https://creativecommons.org/licenses/by-nc/4.0/) which permits unrestricted non-commercial use, distribution, and reproduction in any medium, provided the original work is properly cited.

\subsection{Microfinance Sector in Vietnam}

\subsection{What is microfinance?}

According to Food and Agriculture Organization of the United Nations "Microfinance is the supply of basic financial services to poor and low-income households and their micro-enterprises. Microfinance comprises of several financial tools such as savings, credit, leasing, insurance and cash transfers" (FAO, 2005). Meanwhile, Asia Development Bank states that "microfinance is to provide financial services such as deposits, lending, payment services and insurance for poor people, low-income households and their micro, small businesses" (ADB, 2010). Banking with the Poor Network (2008) provided a definition stating that "Microfinance in Viet Nam has its roots in government social protection measures for the poor. Because the vast majority of the poor population lives in 
rural areas, microfinance has traditionally been interpreted as the market for financial services for rural households"

In short, it can be defined that microfinance is the provision of financial products and services for the poor, the low-income households and micro enterprises to satisfy their needs of expenditure and investments in manufacturing and business.

\subsubsection{Microfinance development in Vietnam}

Although the microfinance industry in Vietnam is quite young in comparison to the ones in other countries, this sector has been rapidly developing into a financial market. According to Le Thi Lan (2010), the history of microfinance in Vietnam is categorized into 3 specific periods: (1) the initial (before 1980); (2) the rapid expansion (1990-2000) and (3) the enduring developing orientation (from 2000 to present).

The initials: Traditional microfinance has appeared for decades and closely associated with micro-agriculture economics, self- sufficiency and village lifestyle. During this period, microfinance played a larger role in supporting people or families struggling with financial problems or unstable life rather than in the role of economic development.

The rapid expansion: A wide range of donor-funded projects from NGOs, international organizations, bilateral projects with different trial models started working in Vietnam, and can be classified into 3 categories: (i) the model that specializes in providing saving and credit services to poor women through Women's Union or sociopolitical organizations - this model is often funded by NGOs; (ii) the integrated model that links credit services to other social-oriented activities such as education, health, housing, clean water and environment, in which credits is merely a small part; (iii) the cooperating model between social organizations like Vietnam Women's Union and commercial banks (for example the project VIT91/P01 between Vietnam Bank for Agriculture and Rural Development and the Central Women's Union).

The enduring development: In the early $21^{\text {st }}$ century, a large number of microfinance projects and programs in Vietnam had to shut down their operations. Others had endeavored to survive by transforming into social funds which were recognized as legal entity under Decree No. 148/2007/NĐ-CP (which was replaced by Decree No. 30/2012/NĐ-CP issued on 12/4/2012). The Decree prescribed the organization and operation of charity and social funds. In 2005, a new legal framework was created in order to facilitate potential microfinance institutions in semi-formal sector to convert into formal microfinance institutions, which are put under the management and supervision of the State Bank of Vietnam. The new framework included Decree 28/2005/NĐ-CP, Decree
165/2007/NĐ-CP and Law on Credit Institutions issued in 2010.

\subsubsection{Classification of microfinance sector in Vietnam}

According to the United Nations Environment Program (UNEP, 2015) - A microfinance institution is an organization that provides financial services and targets people who are poor and low-income. Although there are different types of MFIs, these organizations still have a common characteristic of providing financial services to the poor segment of society where traditional banks often leave. The main objective of MFIs is to develop sustainably to meet the financial needs of the market and customers. According to ADB (2010), microfinance providers in Vietnam are divided into three categories, formal MFIs, semi-formal MFIs and informal MFIs, which focus on different target market segments and market shares.

Table 1: Classification of MFIs in Vietnam

\begin{tabular}{|c|c|c|}
\hline \multicolumn{3}{|c|}{ Microfinance providing institutions } \\
\hline Formal & Semi-formal & Informal \\
\hline Commercial banks & $\begin{array}{c}6 \text { organizations with } \\
50 \% \text { customers of } \\
\text { microfinance }\end{array}$ & Informal groups \\
\hline $\begin{array}{c}\text { Vietnam Bank for } \\
\text { Social Policies }\end{array}$ & $\begin{array}{c}44 \text { organizations with } \\
\text { limited scale }\end{array}$ & $\begin{array}{c}\text { Relatives, family, } \\
\text { friends }\end{array}$ \\
\hline $\begin{array}{c}\text { Microfinance } \\
\text { poopram in Women's } \\
\text { Union of different } \\
\text { cities/town }\end{array}$ & Personal lending \\
\hline People credit funds & & \\
\hline $\begin{array}{c}\text { Formal microfinance } \\
\text { institutions }\end{array}$ & & \\
\hline
\end{tabular}

Source: ADB (2010), Anh (2013)

\section{Introduction to fintech and Fintech in Vietnam}

\subsection{Introduction to fintech}

There is no exact definition of financial technology. However, it can be understood as the application of innovative technology in financial sector with the purpose of providing customers with more convenient and efficient services at a lower cost than traditional banking. Professor Patrick Schueffel (2016) of the Friborg School of Management, after reviewing more than 200 published scholarly papers relating to fintech terminology, provided the definition: "fintech is a new financial industry that 
applies innovative technology to improve financial operations".

According to The Fintech Revolution (2015), fintech is promised to remarkably change the financial industry by lowering costs, enhancing the quality of financial services as well as constituting a more diverse and durable financial prospect. Due to the rapid development of technological infrastructure, big data, data analytics and mobile devices, fintech startups are able to provide unique niche and personalized services to customers and challenge various aspects in the business model of traditional financial institutions. In the report of PwC (2016), traditional financial firms need to establish capabilities to leverage and/or invest in fintech in order to remain competitive.
The growth of investment in Fintech has been a global phenomenon. According to Accenture (2018), global investment in fintech ventures reached another all-time high" in 2017, sustaining the increasing trend of investment seen from 2010. In particular, fintech financing in 2017 reached 27.4 billion, a $18 \%$ increase in comparison to 2016 . The number of fintech deals also rose sharply from just over 1800 deals in 2016 to nearly 2700 in 2017. Geographically, North America accounts for more than half of all investments between 2010 and 2017, in which the U.S is the leading country. Lagging behind North America are Europe and Asia with the outstanding surge in funding for fintech comes from the UK, India and China.

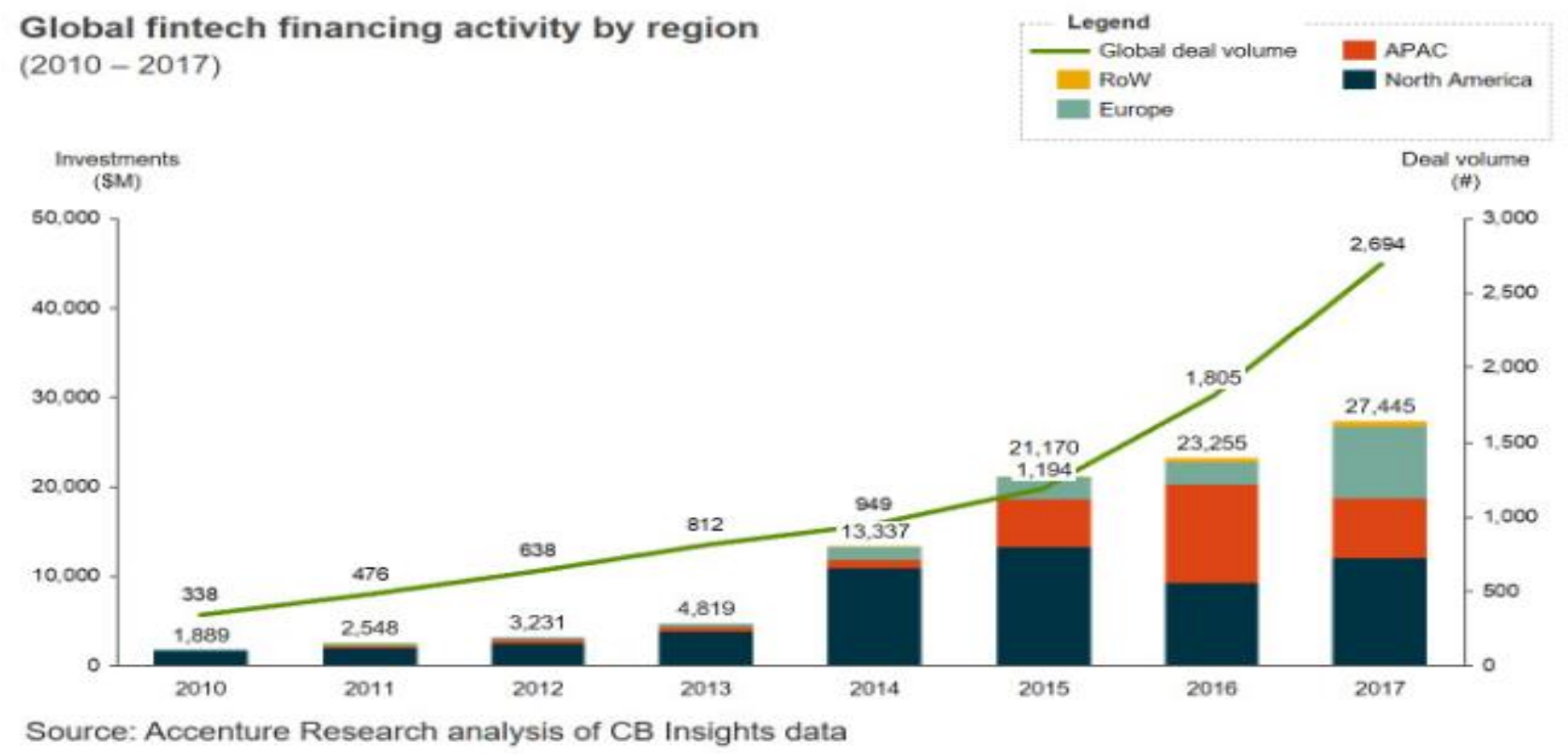

Figure 1: Global fintech financing activity by region

Accenture (2016) points out that traditional financial institutions play an active role in this increase of fintech investment. They invest in external startups in the form of collaborative fintech ventures, as well as their internal fintech projects in order to pursue fintech innovation and gain competitive advantage.

According to the annual fintech 100 report published by KPMG (2015), China and the U.S. are leading countries in fintech startups and companies. The fintech 100 companies in 2015 include 25 payments and transactions companies, 22 lending companies, 14 wealth management companies, and 7 insurance companies (KPMG, 2015). Holland Fintech (2015) forecasts that approximately $\$ 660$ billion in revenue may migrate from traditional financial services to fintech services in the areas of payments, crowdfunding, wealth management, and lending.

It is clear from the evidence that fintech is now well beyond the stage of hype and has become a major player in the financial world

\subsection{Fintech ecosystem}

The growth of the fintech industry requires a stable symbiotic fintech suggests that government, financial institutions and entrepreneurs are the three participants in the fintech ecosystem. PWC (2014) documents that in order to maintain an effectively functioning fintech ecosystem, it is essential that each component certainly understands its role and the interest it is able to gain from close 
involvement with each other (Exhibit 2). In particular, governments must create a favorable regulatory environment that strongly supports the development of the fintech ecosystem. Doing so is a great inspiration for fintech entrepreneurs as well as financial and technology firms. It also contributes to the improvement of the country's financial system and overall competitiveness.

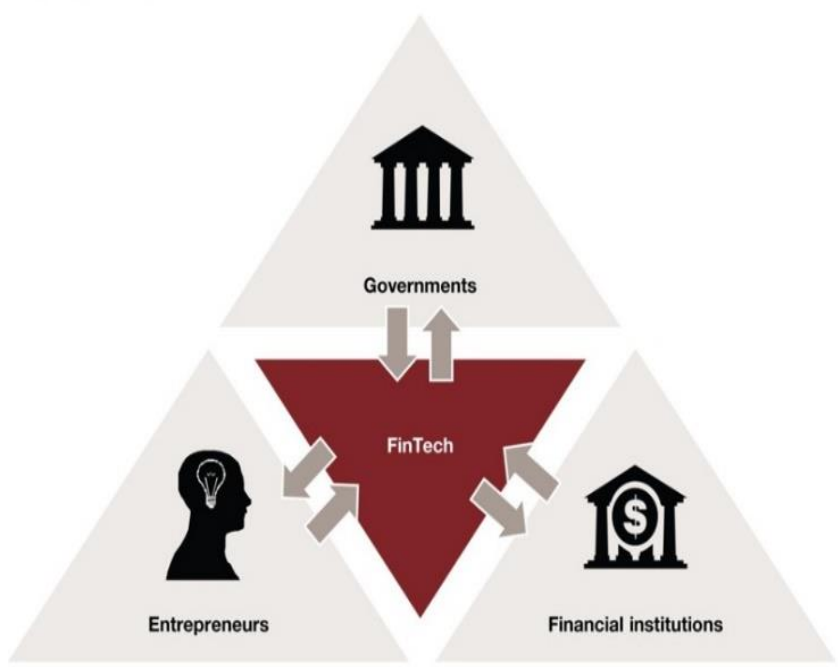

Source: PWC (2014)

Figure 2: Major participants in the Fintech ecosystem

Financial institutions, from another aspect, could provide the system with deep content and market expertise. Meanwhile, the traditional financial institutions can improve their innovation by establishing partnerships with fintech startups. These collaborations indeed can stimulate the competitiveness of traditional financial institutions. For example, by adopting the forefront of technology, the traditional financial institutions are able to diversify their activities by providing more specialized products and services. Entrepreneurs contribute innovative and often disruptive technology solutions to the fintech ecosystem. In return, entrepreneurs benefit from greater access to financing and market expertise, as well as a receptive market for their innovations. Lee and Shin (2018) identifies two more elements that play an essential role in the fintech ecosystem, which are technology developers (such as big data analytics, cloud computing, cryptocurrency and social media developers) and financial customers including both individuals and organizations (Exhibit 3).

Technology developers provide digital platforms such as social networks, big data analytics, cloud computing, artificial intelligence, smartphones and mobile services, among others Technology developers create a favorable environment for start-up companies to deploy innovative services quickly. Social media enhances the growth of network of people in crowdfunding and P2P lending services. Big data analytics can be empowered to offer more personalized products and services at lower costs. Algorithmic trading can be used as the basis of roboadvisor in wealth management. In turn, fintech industry is the source of revenue for technology developers.

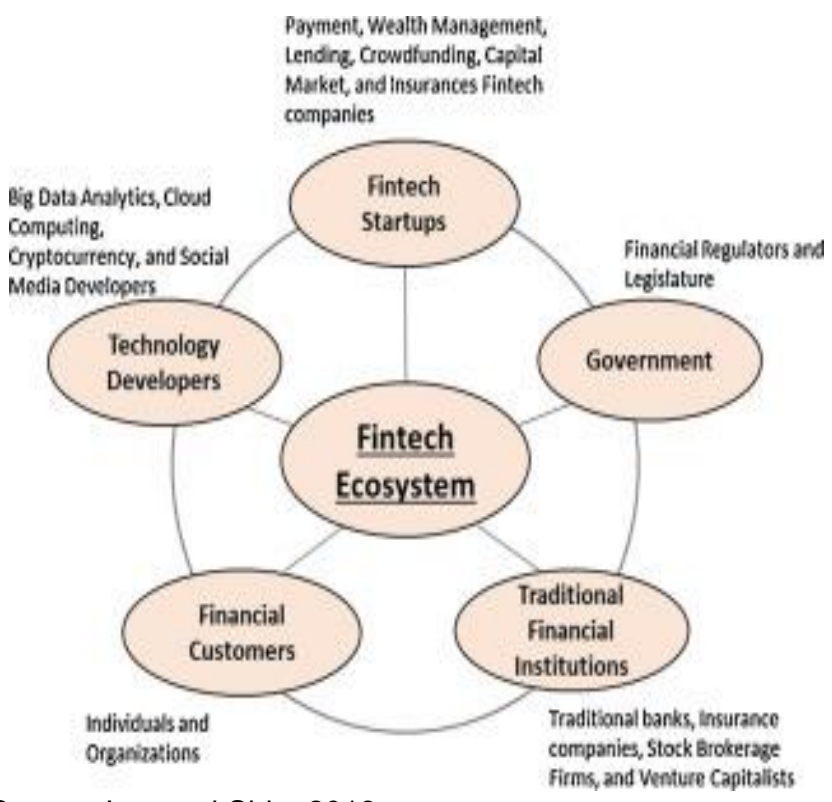

Source: Lee and Shin, 2018

Figure 3: The five elements of the fintech ecosystem

With regard to financial customers, the major revenue source of fintech companies come from individuals and small and medium-sized enterprises. According to Holland Fintech (2015), fintech users currently tend to be technology-trending, younger, urban and higher-income people. Millennials, who are between 18 and 34, now account for an essential proportion of fintech adoption in most countries. Obviously, the future demographic is favorable to fintech startups because technology-trending millennials will constitute the largest part of the population and will lead the trend of fintech growth in the next few decades.

\subsection{Fintech business models}

In the vast growth of the fintech industry, fintech startups have implemented different business models. Lee and Shin (2018) have identified six fintech business models, including payment, wealth management, crowdfunding, lending, capital market and insurance services. The characteristics of each type of business model are discussed below. 


\subsubsection{Payment business model}

Among a wide range of financial products and services, payments are simpler than others. Fintech companies specializing in payments can still create differences in this segment by continuously innovating and adopting new payment capabilities, which enable them to provide rapid services at lower costs. The growing capabilities of fintech in both the consumer/retail and wholesale/corporate payment-arenas as well as antecedent role in shaping the course of the payments industry as a whole. BNY Mellon (2015) documents that consumer and retail payment fintechs consist of mobile wallets, peer-topeer mobile payments, remittances and foreign exchange, real-time payments and digital currency solutions. Among those, mobile payments on mobile devices are a popular model. Mobile payments could consist of barcode or QR code, near field communication (with some well-known mobile applications such as Google Wallet, Apple Pay, Samsung Pay), paying a phone bill, a credit card on mobile websites or direct mobile payment (Li, 2016). P2P payment is another popular fintech business model with some famous apps such as PayPal and Venmo.

\subsubsection{Wealth management business model}

The most popular fintech wealth management business model is automated wealth managements, which can be named robo-advisors. These robo-advisors use algorithms to provide financial advice on investment decisions based on customer's investment preferences and characteristics (Ask the Algorithm, 2015). This business model stems from the change in consumer behaviors that prefer automated and passive investment, simpler and more transparent fee structure, and unit economics that allow low or no investment minimums (Fintech, 2015).

A survey by the CFA Institute in April 2016 found the majority of survey participants to be most concerned about the disruptive characteristics these fintech companies would have in the wealth management sector (Sanicola, 2016). Wealth management fintechs include Betterment, Wealthfront, Motif, and Folio.

\subsubsection{Crowdfunding business model}

Crowdfunding is a way of raising funds for creators of new products, projects or ideas from networks of people. The new products, projects or ideas might be charities or venture capital. Crowdfunding involves three parties, including the project founder or entrepreneur who contributes funds, the contributors who might be interested in providing money for the project and the connecting organization that assists the engagement between the contributors and the founder. The connecting organization provides detailed information about the various initiatives for the contributors to consider whether to invest in the projects or not. A project might be the selection for a number of different investors. There are three most popular types of crowdfunding fintech: donation-based crowdfunding, rewards-based crowdfunding, and equitybased crowdfunding.

Donation-based crowdfunding is a way to raise money for a charity by asking the contributors to donate money to the project. In this kind of crowdfunding, the benefactors receive nothing. Some examples of donation-based crowdfunding include GoFundMe, GiveForward, and FirstGiving.

Reward-based crowdfunding is preferred by a wide range of small businesses and innovative projects to raise funds. According to Mollick (2014), in cases where the contributors require any interest to be charged on the amount of money invested, the borrower is allowed to set the rate that they are comfortable with and guarantee a refund within the specified time period. The return for funds from contributors of a particular project may be some type of a rewards. The size of the reward is usually a reflection of the amount contributed. Some popular names of reward-based crowdfunding comprise of Indiegogo and Kickstarter.

Equity-based crowdfunding enables entrepreneurs to connect with contributors interested in holding equity of the startup or being a private owner of small business. In particular, a portion of the ownership of the fund-raising entrepreneurs is exchanged for the funds from the investors. This type of crowdfunding is potentially suitable with small and medium-sized companies, which are less prioritized customers of traditional banks. Equitybased crowdfunding companies include AngelList, Early Shares, and Crowdcube.

\subsubsection{Lending business model}

Another prevailing trend in fintech is $\mathrm{P} 2 \mathrm{P}$ lending model, which allows individuals and businesses to borrow and lend between each other. P2P lending fintechs are distinguished from traditional banks in the notion that these fintechs are not involved in the money transfers between the lenders and the borrowers but that they simply match the former with the latter and charge fees of users. Williams-Grut (2016) documents that due to this distinction, P2P lending fintechs are currently not required to meet the capital requirements that somehow limit the lending of traditional banks.

With the empowerment of innovative credit models, online data sources, data analytics, and P2P lending fintechs have the ability to enhance the lending process and offer low interest rates for lenders and borrowers. Moreover, the operation of this business model is crucially dependent on how interest rates behave, which are not controlled by the fintechs. Prosper, SoFI, Zopa, and Lending Club are some examples of P2P lending fintechs. 


\subsubsection{Capital market business model}

Lee and Shin (2018) imply that capital market business models are widely operating in many areas of capital market, including foreign exchange, trading, investment, and risk management. For example, fintechs are able to lower the costs for individuals and small businesses to engage in foreign currency transactions. Users are enabled to use their mobile devices to do all the steps, such as checking the price and sending/receiving funds in different currencies in real time. With this efficient operating structure, fintech can offer this service at a lower cost, via payment methods that are more familiar with individual customers and businesses. Some of the capital market fintechs are eToro, Magna, Estimize, Robinhood, and Xoom.

\subsubsection{Insurance services business model}

The insurance fintech business model is able to create a more straight-forward relationship between the insurer and the customer. Because of data analytics, the insurer can reach more potential customers and offer the products and services suitable to customers' needs. Traditional insurance companies are gradually integrating fintech activities into their insurance operations. The technology allows the insurance companies to enhance their sources of customers as well as their risk analysis Fintechs insurance services that are rapidly penetrating the insurance industry include Censio, CoverFox, The Zebra, Sureify Labs, and Ladder (Lee and Shin, 2018).

\subsection{Fintech in Vietnam}

Currently, there are about 50 Fintech companies operating in Vietnam, mainly specializing in providing online payment services, such as Onepay, Ngan Luong, Vnpay, and M-service. Furthermore, Vietnam Fintech market includes startups with informal and small-scaled operation in some other areas, such as crowfunding (e.g., FundStart, Comicola, Betado, and Firststep), online lending (e.g., Loan Vi, Tima, Trust, and Circle), personal financial data management (e.g., MoneyLover, Mobivi, and Kiu), customer data management (e.g., CircleBi,-and Trusting Social), digital banking (Timo), financial service (Bankgo and GoBear), and online mortgage (F88).

\section{Opportunities and challenges of Fintech for microfinance industry in Vietnam}

Globally, the strong penetration of non-banking institutions providing fintech services into financial markets has gradually increased its influence on financial systems. This major influence is derived from alternative technology solutions, which are simpler, more efficient and transparent than traditional banking system. Indeed, Fintech is developed on the basis of information technology and telecommunications, which allow Fintech to expand its operation without establishing network of branches and transaction offices. Therefore, Fintech has attracted a large number of customers, especially those living in rural and remote areas who do not have a bank account and are not targeted customers of traditional banks or financial institutions. With the recent remarkable development in Vietnam, Fintech is expected to be an indispensable trend in the next phase of the financial market. Furthermore, with the outstanding advantages such as the ability to optimize users' convenience and provide high quality services with low user fees, Fintech is anticipated to present considerable challenges to the whole financial sector and be a potential competitor of traditional financial institutions.

In Vietnam, microfinance institutions play a vital role in promoting financial inclusion. Therefore, Fintech is expected to effectively support the operation of microfinance in order to achieve mutual object that is to expand the financial inclusion for customers facing various difficulties in approaching formal financial services. In accompanied with opportunities, fintech also faces many challenges such as:

\subsection{Fintech adoption and the opportunity for microfinance sector}

MFIs are considered the financial institutions that target the poor, the low-income people and those living in rural areas. According to the Labor Force Survey of GSO (General Statistics Office of Vietnam) in 2016, Vietnam's population as of December 31, 2016 was 92.7 million, of which the urban population was 31.8 million (34.3\%) and the rural population was 60.9 million $(76.5 \%)$. At the end of 2016, there were 1806 communes which constituted $20.1 \%$ of the total number of communes in the rural areas of Vietnam having the operations of banks, bank branches and People's credit funds. In those communes, there were $30.1 \%$ of total households having demand for bank loans, of which merely $73.1 \%$ of households had access to the funds. Of the total loans, $52.4 \%$ of households borrowed funds from Social Policy Bank, 34.1\% from commercial banks, $3.8 \%$ from support funds and $9.7 \%$ from other sources. It can be seen that the room for microfinance in Vietnam is still high.

In addition, according to Nielsen Vietnam Smartphone Insights Report 2017, 71\% of local people possessed a smartphone amongst $93 \%$ of the population using mobile phones. More remarkably, while $89 \%$ of the people living in rural area owned a mobile phone, $68 \%$ of them used smartphones. Accompanied with the high rate of mobile phone possession is the relatively high rate of internet 
access in Vietnam. This context opens up opportunities for Fintech growth in Vietnam as well as the cooperation between microfinance and Fintech. Watkins, DiLeo, Kanze, and Lieberman (2017) on the blog of Center for Financial Inclusion have indicated that Fintech enables MFIs to build hyper-personalized products, which are able to satisfy widely diverse needs and situations of individual clients and their families. Furthermore, a number of researches and reports about Fintech adoption of microfinance in developing and emerging countries (such as African countries) have shown that MFIs are actively looking for ways to improve customer convenience, raise efficiency and productivity, reduce risks and enhance risk management as well as expand outreach to new markets by leveraging Fintech solutions (Triple Jump, 2018; World Bank and Bank Negara, 2017). Besides, another advantages for the Vietnamese microfinance sector is that the state management agencies, especially the State Bank of Vietnam (SBV), have expended great efforts to establish an appropriate legal framework that support MFIs to grow and integrate step-by-step integrate into financial system.

\subsection{Fintech adoption and the challenges for microfinance sector}

The Vietnamese government, especially SBV, has devoted considerable effort to support microfinance industry's development. However, the effort has been unable to capture the growth of microfinance sector, customer needs for microfinance, or the sector's potential in applying fintech to magnify its customer outreach. In the new context, the cooperation between microfinance industry and Fintech can be seen as a direction toward a strategic development. Utilizing technology innovation of Fintech enables MFIs to improve their competitiveness and better serve customer needs. However, the legal framework related to providing financial and banking products and services on technologically innovative basis in Vietnam is still very modest in comparison to its potential growth.
Indeed, this fact is one of the reasons leading to the restriction of Fintech products and services. Currently, Fintech operations mainly concentrate on traditional activities such as payments and money transfers, which are highly and clearly regulated. Meanwhile, other products, including credits, asset management, and capital mobilization, which are strongest activities of MFIs, are unpopular in Fintech sector.

According to Article 122 of the Law on Credit Institutions (2010), MFIs are not allowed to open payment accounts for customers. Thus, MFIs in Vietnam have not provided payment and money transfer services but have merely focused on two main activities consisting of lending and capital mobilization. This situation obviously limits the opportunities for microfinance sector to adopt Fintech in order to improve its market outreach and achieve sustainable growth.

In terms of challenges of legal framework, there are challenges tailored to MFI customers-characteristics. In detail, MFIs' customers are mainly the poor, the lowincome and micro enterprises who have limited knowledge and skills about technology, especially financial technology. Therefore, in order to successfully adopt Fintech into their operation, MFIs need to pay attention to financial education for their customers.

\section{Regulations on Fintech and microfinance in Vietnam}

In Vietnam, legal framework on fintech has been developed. In that context, building the legal framework for payment activities associated with new payment products and services, in particular, and microfinance activities, in general, are a deep concern for the government, the state bank and other state management agencies. In recent years, many schemes, legal documents related to payment and microfinance have been developed and issued, specifically:

Table 2: Regulatory documents on payment activities and the microfinance sector

\begin{tabular}{|c|c|c|c|}
\hline No. & Law documents & Document number & Content \\
\hline $\mathbf{0 1}$ & $\begin{array}{c}\text { Scheme on building } \\
\text { and developing } \\
\text { Vietnam's } \\
\text { microfinance } \\
\text { system up to 2020 }\end{array}$ & $\begin{array}{c}\text { Decision No. 2195/ } \\
\text { QE-TTg dated } \\
06 / 12 / 2011 \text { of the } \\
\text { Prime Minister }\end{array}$ & $\begin{array}{c}\text { The objective of the scheme is to build and develop a secure, sustainable MFI } \\
\text { system aimed at serving the poor, low-income people, microenterprises and } \\
\text { small businesses; contributing to the implementation of the Party's and State's } \\
\text { policies on ensuring social services and sustainable poverty reduction. }\end{array}$ \\
\hline $\mathbf{0 2}$ & $\begin{array}{c}\text { Scheme on } \\
\text { improving access to } \\
\text { banking services } \\
\text { for the economy }\end{array}$ & $\begin{array}{c}\text { Decision No. 1726/ } \\
\text { QD-TTg dated 5 } \\
\text { September 2016 of } \\
\text { the Prime Minister }\end{array}$ & $\begin{array}{c}\text { The scheme addresses three issues: (i) increasing the banking service delivery } \\
\text { channel; (ii) enhancing the quantity and quality of banking products and services } \\
\text { along with simplifying product designs that enable people and enterprises, } \\
\text { especially those in remote areas too difficult to access; (iii) increasing the use of } \\
\text { banking services. }\end{array}$ \\
\hline
\end{tabular}




\begin{tabular}{|c|c|c|c|}
\hline 03 & $\begin{array}{l}\text { Scheme on } \\
\text { development of } \\
\text { non-cash payment } \\
\text { in Vietnam in the } \\
2016-2020 \text { period }\end{array}$ & $\begin{array}{l}\text { Decision No. } 2545 / \\
\text { QD-TTg dated } \\
\text { 30/12/2016 of the } \\
\text { Prime Minister }\end{array}$ & $\begin{array}{l}\text { The project provides a number of objectives and solutions related to the } \\
\text { application of Fintech to encourage and promote the development of non-cash } \\
\text { payment, including Internet payment services, mobile phones, bank cards, } \\
\text { intermediary payments, and improve access to payment services, in particular, } \\
\text { banking services in general, promoting financial inclusion. }\end{array}$ \\
\hline 04 & $\begin{array}{l}\text { Scheme for } \\
\text { supporting a } \\
\text { national innovative } \\
\text { initiative ecosystem } \\
\text { to } 2025\end{array}$ & $\begin{array}{l}\text { Decision No. } 844 \text { / } \\
\text { QD-TTg dated May } \\
\text { 18, } 2016 \text { of the } \\
\text { Prime Minister }\end{array}$ & $\begin{array}{l}\text { The project aims to create a favorable environment to promote and support the } \\
\text { development of ecosystems, appropriate management mechanisms and the } \\
\text { legal framework to facilitate Fintech businesses in Vietnam. }\end{array}$ \\
\hline 05 & $\begin{array}{l}\text { Law on credit } \\
\text { institutions }\end{array}$ & $\begin{array}{c}\text { Law No. } 47 / 2010 / \\
\text { QH12 of the } \\
\text { National Assembly }\end{array}$ & $\begin{array}{l}\text { The law affirms MFIs are a type of credit institution in the system of credit } \\
\text { institutions of Vietnam, under the control of the State Bank of Vietnam. This is a } \\
\text { great step forward for the microfinance sector. Microfinance providers such as } \\
\text { Vietnam Bank for Social Policies, Cooperatives Bank, Central credit funds and } \\
\text { MFls provide credit, savings, insurance, other financial services, and non- } \\
\text { financial services have opened the door to escape poverty for the people and } \\
\text { are highly appreciated by the poor. }\end{array}$ \\
\hline 06 & $\begin{array}{l}\text { The Decree } \\
\text { stipulates non-cash } \\
\text { payment }\end{array}$ & $\begin{array}{l}\text { Decree No. } \\
101 / 2012 / N D-C P \\
\text { dated } 22 / 11 / 2012 \text { of } \\
\text { the Government }\end{array}$ & $\begin{array}{l}\text { The Decree has created an important legal framework for organizations and } \\
\text { individuals, including MFls involved in payment operations in the economy. }\end{array}$ \\
\hline 07 & $\begin{array}{l}\text { Circular guiding the } \\
\text { opening and use of } \\
\text { payment accounts }\end{array}$ & $\begin{array}{l}\text { Circular No. } \\
\text { 23/2014 / TT-NHNN } \\
\text { dated } 19 \text { August } \\
2014 \text { of the SBV }\end{array}$ & $\begin{array}{l}\text { The Circular provides guidance on the opening and the use of payment accounts } \\
\text { at regulated payment service suppliers. This provision extends the object of } \\
\text { opening an account at a bank, facilitating the payment and keeping the money. } \\
\text { This is also a prerequisite for people to access other financial products and } \\
\text { services, such as credit, insurance, savings and investment. }\end{array}$ \\
\hline 08 & $\begin{array}{l}\text { Circular on } \\
\text { instructions on } \\
\text { intermediary } \\
\text { payment services }\end{array}$ & $\begin{array}{l}\text { Circular No. } \\
\text { 39/2014 / TT-NHNN } \\
\text { dated } 11 / 12 / 2014 \text { of } \\
\quad \text { the SBV }\end{array}$ & $\begin{array}{l}\text { The circular was created to provide legal framework for companies to implement } \\
\text { intermediary payment services, create new payment channels, and promote } \\
\text { financial inclusion in Vietnam. The intermediary payment service providers, } \\
\text { together with the commercial banking system, have provided new payment } \\
\text { solutions to meet the market demand, especially in rural, remote and isolated } \\
\text { areas where banking network is difficult to reach. }\end{array}$ \\
\hline
\end{tabular}

Source: State Bank of Vietnam

\section{Recommendations for Fintech adoption of MFIs in Vietnam}

\subsection{Recommendations for state management agencies}

The State Bank and related agencies should accelerate the research and development of the legal framework for applying Fintech to banking operations, including microfinance. In the event the formal and comprehensive legal framework for the Fintech sector cannot be promulgated immediately, the SBV may consider issuing a trial legal framework, evaluating the advantages, disadvantages, effectiveness as well as potential risks of the pilot model. On that basis, the SBV can promulgate the appropriate framework to the context and conditions of the Vietnamese market.

\subsection{Recommendations for MFIs}

To prepare for Fintech adoption, MFIs would first need to strengthen and expand their core activities through enhancing market research ability, improving the quality of current products and introducing new services associated with Fintech applications, such as saving mobilization, micro insurance services, and collection agents in order to widely meet the diverse needs of customers. In addition to the quantity of services, MFIs need to pay greater attention to service quality, the availability and access level of products and services.

Moreover, improving human resources quality is considered one of the key and long-term solutions for the sustainable growth of MFIs in Vietnam. Therefore, it is essential to improve human resources through professional training. In fact, most of MFIs' staffs are provided by social organizations; thus, the professional qualifications and knowledge of financial and banking operations are still modest. As a result, MFIs need to strengthen their internal training, participate in training courses and, at the same time, adopt appropriate policies to attract and retain qualified staffs to meet the requirements of technological applications.

In addition, most microfinance clients are currently not familiar with Fintech solutions. Thus, in order to apply Fintech in microfinance industry, MFIs might consider the following approach:

- Lending activities in MFIs in Vietnam are often delivered through lending groups, and MFIs' customers have tendency 
to trust group leaders. Therefore, MFIs should choose group leaders who are qualified and able to understand Fintech solutions that tailor to their microfinance products in order to better give instruction to other members

- The application of digital finance must be implemented through gradual stages, first to form customers' habit of using financial technological products and services. Initially, customers might use applications on mobile phones, which are connected to their accounts in MFIs to check account balances, receive or transfer small amounts of money, such as to purchase phone card. Through such steps, customers will gradually increase their knowledge and confidence when using digital finance solutions and then progress to other more complicated services, such as online savings, insurance, money transfer and payment.

\section{Conclusion}

It can be seen that Fintech and banking and finance industries have become a global trend. Microfinance institutions in Vietnam should, therefore, pay more attention to research and invest in digitization of records and customer data, as the basis for the powerful and effective application of new technologies and Fintech to improve efficiency.

\section{References}

Accenture. (2016). Global Fintech investment growth continues in 2016 driven by Europe and Asia. Accenture study finds. Retrieved August10, 2019, from https://newsroom.accenture.com/news/global-Fintechinvestment-growth-continues-in-2016-driven-by-europe-andasia-accenture-study-finds.htm

Accenture. (2018). Global Venture Capital Investment in Fintech Industry Set Record in 2017 driven by Surge in India, US and UK. Accenture Analysis Finds. Retrieved August 08, 2019, from https://newsroom.accenture.com/news/global-venturecapital-investment-in-fintech-industry-set-record-in-2017driven-by-surge-in-india-us-and-uk-accenture-analysisfinds.htm

Asian Development Bank (ADB). (2010). Viet Nam Microfinance Sector Assessment and Key Elements to a Microfinance Strategy: Preparing Microfinance Development Program. Grant Assistance Consultants' Report August 2010. Retrieved August 09, 2019, from

https://www.adb.org/sites/default/files/projectdocument/75628 /42235-012-vie-tacr.pdf

Banking with the Poor Network (2008). Microfinance Industrial report: Vietnam. Retrieved from https://www.economica.vn/Portals/0/Documents/d82c531e8c8 40757b4097a57212883c0.pdf

BNY Mellon. (2015). Innovation in payments: The future is Fintech. Retrieved July 22, 2019, from https://www.bnymellon.com/_global-assets/pdf/ourthinking/innovation-in-payments-the-future-is-Fintech.pdf

Diemers, D., Lamaa, A., Salamat, J., \& Steffens, T. (2015). Developing a Fintech ecosystem in the GCC. Retrieved July 07, 2019, from

http://www.strategyand.pwc.com/media/file/Developing-aFintech-ecosystem-in-the-GCC.pdf

Food and Agriculture Organization of the United Nations (2005). Microfinance and forest-based small-scale enterprises. Retrieved from http://www.fao.org/3/a0226e/a0226e00.htm\#TopOfPage

Holland Fintech. (2015). The future of finance: The socialization of finance. Retrieved August 14, 2019, from http://hollandFintech.com/the-future-of-finance-thesocialization-of-finance/

KPMG. (2015). H2 Ventures KPMG Fintech 100: Announcing the world's leading Fintech innovators for 2015. Retrieved August 19, 2019, from https://home.kpmg.com/xx/en/home/insights/2015/12/ventures -kpmg-Fintech-fs.html

Le, T. L. (2010). Building Vietnam's microfinance industry towards sustainable development to achieve the goals of poverty reduction. Hanoi, Vietnam: Microfinance Working Group.

Lee, I. (2016). Encyclopedia of e-commerce development, implementation, and management. Current and future years of e-commerce, 2016, 1031-1044.

Lee, I., \& Shin, Y. J. (2018). Fintech: Ecosystem, business models, investment decisions, and challenges. Business Horizons, 61(1), 35-46.

Mollick, E. (2014). The dynamics of crowdfunding: An exploratory study. Journal of Business Venturing, 29(1), 1-16.

Nguyen, K. A., \& Le, T. T. (2013). Sustainable level of microfinance institutions in Vietnam: The practices and some recommendations. Hanoim, Vietnam: Giao thong van tai Publisher.

Patrick Schueffel. (2016). Taming the Beast: A Scientific Definition of Fintech. Journal of Innovation Management, 4(4), 32 - 54. Retrieved July 17, 2019, from https://hesso.tind.io/record/1996/files/Schueffel_Tamingthebe ast_2016.pdf

PwC (2014). Developing a Fintech ecosystem in the GCC. Retrieved from https://www.strategyand.pwc.com/m1/en/reports/developinga-fintech-ecosystem-in-the-gcc.pdf

PwC. (2016). Blurred lines: How Fintech is shaping financial services. Retrieved August 14, 2019, from https://www.pwc.de/de/newsletter/finanzdienstleistung/a ssets/insurance-inside-ausgabe-4-maerz-2016.pdf

Sanicola, L. (2016). Will Fintech help or hurt traditional advisors? CNBC. Retrieved August 28, 2019, from http://www.cnbc.com/2016/05/25/will-Fintech-help-or-hurttraditional-advisors.html

SparkLad. (2016). Fintech - Industry report 2016.

The Economist. (2015). Ask the algorithm: Human wealth advisers are going out of fashion. Special Report Slings and Arrows, 415(8937), 11.

The Fintech revolution: A wave of startups is changing financefor the better. (2015). The Economist, 415(8937), 13. 
Triple Jump. (2018). How microfinance is navigating the Fintech revolution in Africa: Exploring the opportunities and challenges of Fintech formicrofinance institutions. Retrieved June 27, 2019, from https://triplejump.eu/wpcontent/uploads/2018/05/How-Microfinance-is-Navigatingthe-Fintech-Revolution-in-Africa-1.pdf

Vietnam News. (2017). Smartphone users cover $84 \%$ of VN population. Vietnam News. Retrieved August 16, 2019, from https://vietnamnews.vn/economy/418482/smartphone-userscover-84-of-vn-population.html\#ZbvEc0hbUgqBwDiL.97

Watkins, T. A., DiLeo, P., Kanze, A., \& Lieberman., I (2017). Fintech in Microfinance: In Search of the High-Tech HighTouch Unicorn? Retrieved July 17, 2019, from https://cfi- blog.org/2017/05/11/fintech-in-microfinance-in-search-of-thehigh-tech-high-touch-unicorn/

Williams-Grut, O. (2016). Deloitte just trashed the hype around a $\$ 180$ billion Fintech market. Business Insider. Retrieved August 14, 2019, from http://www.businessinsider.com/deloitte-report-marketplacelending-not-significant-players-peer-to-peer-2016-5

World Bank Group \& Central Bank of Malaysia. (2017). Revolutionizing Microfinance: Insights from the 2017 Global Symposium on Microfinance. Retrieved August 29, 2019, from

http://pubdocs.worldbank.org/en/332301505318076916/GSM 2017-Synthesis-report-draft-August-9th-2017-Final.pdf 